\title{
Pre-Treatment Biomarkers of Anti-Tumour Necrosis Factor Therapy Response in Crohn's Disease-A Systematic Review and Gene Ontology Analysis
}

\author{
Boris Gole $^{1, *}$ and Uroš Potočnik ${ }^{1,2, *}$ \\ 1 Centre for Human Molecular Genetics and Pharmacogenomics, Faculty of Medicine, University of Maribor, \\ Taborska ulica 8, SI-2000 Maribor, Slovenia \\ 2 Laboratory for Biochemistry, Molecular biology and Genomics, Faculty of Chemistry and Chemical \\ Engineering, University of Maribor, Smetanova ulica 17, SI-2000 Maribor, Slovenia \\ * Correspondence: boris.gole@um.si (B.G.); uros.potocnik@um.si (U.P.); \\ Tel.: +386-(2)-243-58-53 (B.G.); +386-(2)-234-58-54 (U.P.); Fax: +386-(2)-234-58-20 (U.P.)
}

Received: 15 April 2019; Accepted: 25 May 2019; Published: 28 May 2019

\begin{abstract}
The most prominent treatment for the serious cases of Crohn's disease (CD) are biological tumour necrosis factor (TNF) inhibitors. Unfortunately, therapy nonresponse is still a serious issue in $\sim 1 / 3$ of CD patients. Accurate prediction of responsiveness prior to therapy start would therefore be of great value. Clinical predictors have, however, proved insufficient. Here, we integrate genomic and expression data on potential pre-treatment biomarkers of anti-TNF nonresponse. We show that there is almost no overlap between genomic (annotated with tissue-specific expression quantitative trait loci data) and transcription (RNA and protein data) biomarkers. Furthermore, using interaction networks we demonstrate there is little direct interaction between the proposed biomarkers, though a majority do have common interactors connecting them into networks. Our gene ontology analysis shows that these networks have roles in apoptotic signalling, response to oxidative stress and inflammation pathways. We conclude that a more systematic approach with genome-wide search of genomic and expression biomarkers in the same patients is needed in future studies.
\end{abstract}

Keywords: Crohn's disease; inflammatory bowel disease; anti-tumour necrosis factor; adalimumab; infliximab; certolizumab pegol; therapy response; biomarker

\section{Introduction}

Crohn's disease (CD) is one of the two principal subtypes of Inflammatory Bowel Disease (IBD), a chronic autoimmune condition that may affect any part of the digestive system and seriously affects the quality of life [1-3]. The serious cases of CD/IBD are treated with biologicals, most prominently with tumour necrosis factor (TNF) inhibitors. Unfortunately, $20-40 \%$ of patients (in clinical studies) fail to respond to treatment while $23-46 \%$ of patients loose response over time [4,5]. Non-responsiveness to anti-TNF therapy in CD is therefore an important issue, both for patients who are exposed to potentially severe side-effects of the therapy that they do not benefit from, and for the healthcare systems that need to pay for the expensive yet inefficient treatment. With novel biologicals against alternative targets, such as ustekinumab (anti-IL12/23) and vedolizumab (anti- $\alpha_{4} \beta_{7}$ integrin) for treatment of CD/IBD and thus possibility of greater stratification of the patients [6], pre-emptive prediction of non-response to anti-TNF is becoming even more meaningful.

Unfortunately, current clinical predictors of response to anti-TNFs do not satisfactorily predict the response. Genetic background and gene expression are therefore also under investigation [7-13]. There are several recent reviews on the topic, focusing either on clinical prediction of anti-TNF response $[2,4,5,14,15]$ or summarizing genomic and/or expression data and proposing predictive sets 
of anti-TNF response markers [16-20]. Here, for the first time we integrate genomic and expression markers that could predict non-response to anti-TNF treatment in CD patients prior to treatment initiation into common interaction networks. We also use gene ontology (GO) tools to obtain some insight into signalling pathways/biological processes where future biomarkers of the anti-TNF therapy failure in the CD patients may hide.

\section{Materials and Methods}

\subsection{Information Sources and Search, Study Selection}

The PRISMA statement (http://www.prisma-statement.org/) was followed while conducting the present study. An electronic literature search of the PubMed was performed on November 30th, 2018. The search terms used were Crohn's disease, Inflammatory Bowel Disease; anti-TNF, infliximab, adalimumab, golimumab, entanercept, certolizumab; response, non-response, outcome, therapy, treatment, prediction. Only publications in English language were eligible. Both U.K. and U.S. spellings were taken into account (i.e., tumour/tumor necrosis factor). The full search strategy including final query translation is described in Supplementary Methods.

We included studies reporting on genetic and/or expression (RNA, protein) biomarkers predicting response to anti-TNF biologicals in adult $\mathrm{CD}$ patients measured at baseline (i.e., prior to therapy start). Study selection was performed in several rounds. Full selection process is described in Supplementary Methods.

\subsection{Data Collection and Integration}

We collected data on genomic biomarkers and expression biomarkers measured in blood (peripheral blood mononuclear cells-PBMCs or serum) and colon (colon mucosa, stool) of CD patients prior to the anti-TNF therapy start. We collected all the relevant data regardless of the therapeutic used (infliximab, adalimumab, golimumab, unspecified) or how the clinical response was assessed (CDAI-Crohn's Disease Activity Index, HBI—Harvey-Bradshaw Index, IBDQ—Inflammatory Bowel Disease Questionnaire, clinical assessment, etc.). Depending on the time-point of therapy response assessment we separated short-term response (week 2-22) and long-term response ( $>6$ months).

As genomic markers we collected data on all the SNPs (single-nucleotide polymorphisms) which were connected to anti-TNF therapy response with a $p$-value $<0.05$. The $p$-values corrected for multiple testing were also collected. If only uncorrected $p$-values were reported the adjusted $p$-values were calculated using Bonferroni correction-these adjusted $p$-values are marked with italics. To compare genomic markers to expression data only tissue-specific eQTL (expression Quantitative Trait Loci) data were acknowledged-Colon-sigmoid, Colon-Transverse and Small Intestine eQTLs to compare with colon mucosa expression data and blood eQTLs to compare to blood cells and serum expression data. The eQTL data were obtained from the GTEx Portal (https://www.gtexportal.org) on March 1st, 2019.

As expression biomarkers we collected the quantified data on RNA and proteins measured in anti-TNF therapy responders (Re) and nonresponders (NR) prior to therapy start. For mRNA individual qRT-PCR and microarray data were screened and biomarkers with log2 difference in expression level (NR to Re) of at least 1.5-fold collected; $p$-values adjusted for multiple testing $<0.05$ were defined as significant. From individual qRT-PCR experiments the $\Delta \Delta \mathrm{Ct}$ values were extracted. If only uncorrected $p$-values were reported the adjusted $p$-values were calculated using Bonferroni correction-these adjusted $p$-values are marked with italics. We downloaded microarray data from GEO database (https: //www.ncbi.nlm.nih.gov/geo/). The log2-transformed fold differences in expression and the $p$-values were calculated with GEO2R available at GEO website based on LIMMA package. The $p$-values were adjusted with Benjamini-Hochberg method (False Discovery Rate). For RNA expression biomarkers in blood cells the uncorrected $p<0.05$ was defined significant since none of the biomarkers met the adjusted $p<0.05$ criterion. The probe annotations were determined using NetAffx Analysis Center (https://www.affymetrix.com/analysis) and BioMart (https://www.ensembl.org/biomart) services. 
At protein level all quantifiable data (ELISA, immunohistochemistry, immunofluorescence, etc.) data were screened and biomarkers with $>1.5$-fold difference in expression level (NR to Re) extracted. The significance was defined at a $p$-value $<0.05$. For comparison of complex protein data with RNA and genomic data all the genes coding for the subunits of the protein complex were designated the same fold change and $p$-value.

\subsection{Interactome Builds and Gene Ontology (GO) Analysis}

Interactomes of the biomarkers were build with CytoScape platform (version 3.5.1, CytoScape Consortium, San Diego, CA, USA) based on protein-protein interactions downloaded from BioGrid database (version 3.5.170; https://thebiogrid.org) on March 6th, 2019. Besides interactions between biomarkers we also included the genes/proteins interacting directly with the biomarkers (interactors). To simplify the interactomes and avoid bias due to unequal numbers of interactors of individual biomarkers, the interactors connected to only single biomarkers were omitted from the network. GO analysis of biomarkers and of the whole interactomes was done within the CytoScape platform using the ClueGO plug-in (version 2.5.2, INSERM, Paris, France). Details on GO analysis settings are described in Supplementary Methods.

\section{Results}

\subsection{Literature Search}

The electronic literature search yielded 9763 hits (Figure 1). The 9386 hits were either automatically excluded based on publication type (case reports, retracted publications, publications not reporting novel measurements, i.e., reviews, editorials, etc.) or excluded after manual screening for obviously irrelevant studies and studies not reporting data on adult CD patients (reporting experimental in vitro or animal data, data on ulcerative colitis, data on paediatric IBD). The remaining 377 publications were assessed for eligibility. The 301 publications not reporting on genomic or expression biomarkers, not comparing nonresponders to responders, not presenting separate data on CD patients, or reporting only expression data after therapy start were excluded. Additionally, we excluded nine more publications not reporting novel data $(3 \times$ erratum, $1 \times$ study proposal, $2 \times$ commentary and $3 \times$ review not detected by automatic exclusion) and one where it was impossible to determine whether the data were collected pre- or post-therapy start. The remaining 66 publications (Supplementary Table S1) were included in the systematic review. Data on genomic and expression markers for GO analysis were extracted from 40 of these. The rest either reported only negative results, or the reported differences did not reach the $p$-value significance or fold change required for inclusion (see Methods). 


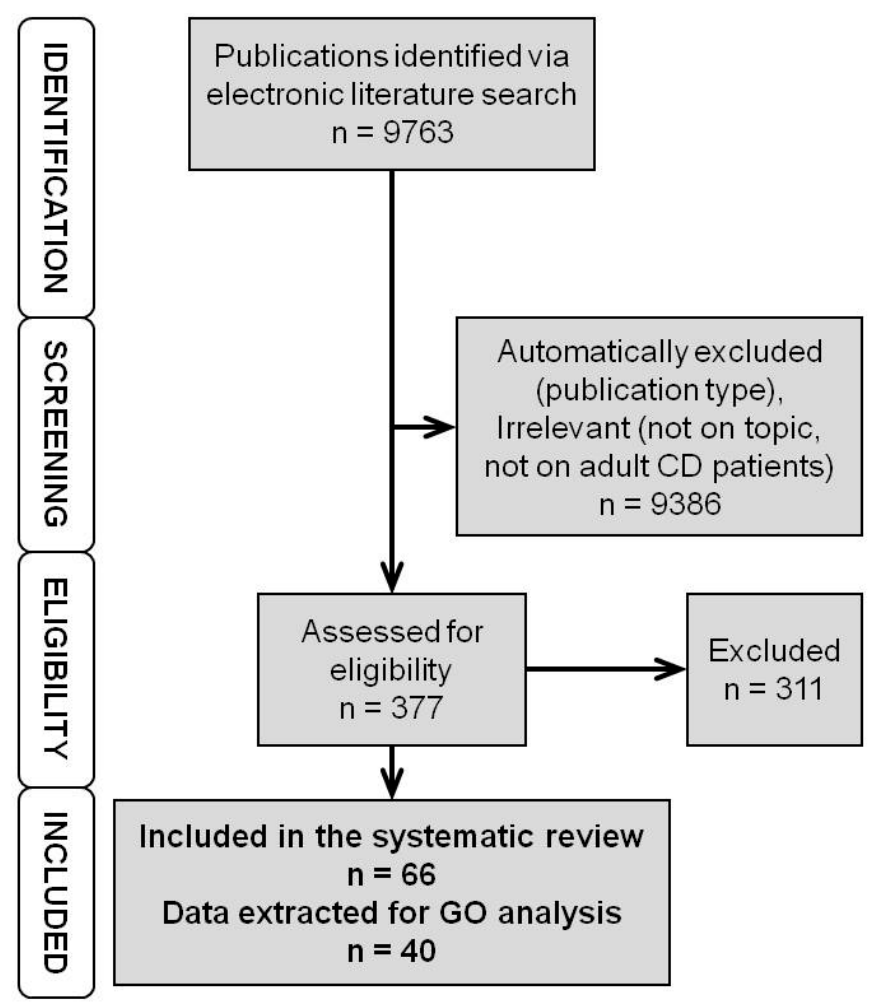

Figure 1. Flowchart of the literature search and selection. First, we identified the publications via electronic literature search. Then, using automatic screening, we excluded publication types not reporting new measurements/data and with manual screening irrelevant studies. The remaining publications were assessed for eligibility. Those reporting suitable (quantifiable) data on genomic or expression markers of anti-TNF response measured prior to therapy start were included in the systematic review. (TNF - Tumour Necrosis Factor, CD - Crohn's Disease, GO - Gene Ontology).

\subsection{Genomic Markers}

We identified 40 studies trying to connect DNA sequence variability, i.e., single-nucleotide polymorphisms (SNPs) to anti-TNFs response in CD patients (Supplementary Table S1). Almost half of these studies (18/40) reported only negative results. The rest reported 72 SNPs connected to shortand 34 SNPs connected to long-term response to anti-TNF therapy in CD patients with a $p<0.05$ (Supplementary Tables S2 and S3, respectively). When the $p$-values are adjusted for multiple testing, 18 SNPs remain connected to short- and 3 SNPs connected to long-term response (Table 1). None of these SNPs has a confirmation in an independent patient cohort (without $p$-value adjustment four SNPs have independent confirmation-Supplementary Table S2). The SNP most significantly associated to both short- and long-term anti-TNFs response in CD patients after $p$-value adjustment is rs1130864, a $3^{\prime}$-UTR variant of the CRP gene (adjusted $p=4.09 \times 10^{-4}$ ). 
Table 1. Single-Nucleotide Polymorphisms (SNPs) linked to anti-TNF response in CD patients with adjusted $p<0.05$.

\begin{tabular}{|c|c|c|c|c|c|}
\hline SNP & $p$-Value & $\begin{array}{c}\text { Adjusted } \\
p \text {-Value }\end{array}$ & \multicolumn{2}{|c|}{ Allele/Genotype Association } & Reference \\
\hline \multicolumn{6}{|c|}{ short-term response } \\
\hline rs1130864 & $4.09 \times 10^{-5}$ & $4.09 \times 10^{-4}$ & $\mathrm{C}$ & $\operatorname{Re}$ & [8] \\
\hline rs763110 & N.D. & $1.00 \times 10^{-3}$ & $\mathrm{CC} / \mathrm{CT}$ & $\operatorname{Re}$ & [21] \\
\hline rs12469362 & N.D. & $1.30 \times 10^{-3}$ & $\mathrm{~T}$ & $\operatorname{Re}$ & [22] \\
\hline rs10495565 & N.D. & $1.40 \times 10^{-3}$ & G & $\operatorname{Re}$ & [22] \\
\hline rs1056204 & N.D. & $1.40 \times 10^{-3}$ & $\mathrm{C}$ & $\operatorname{Re}$ & [22] \\
\hline rs4464248 & N.D. & $1.80 \times 10^{-3}$ & G & $\operatorname{Re}$ & [22] \\
\hline rs396991 & $3.00 \times 10^{-3}$ & $3.00 \times 10^{-3}$ & GG & $\operatorname{Re}$ & [23] \\
\hline rs1813443 & $2.00 \times 10^{-3}$ & $6.00 \times 10^{-3}$ & $\mathrm{CC}$ & NR & [24] \\
\hline rs9373839 & $1.13 \times 10^{-3}$ & $1.13 \times 10^{-2}$ & $\mathrm{C}$ & $\operatorname{Re}$ & [8] \\
\hline rs2071303 & $8.20 \times 10^{-3}$ & $1.64 \times 10^{-2}$ & G & $\operatorname{Re}$ & [9] \\
\hline rs1061624 & $5.00 \times 10^{-3}$ & $2.00 \times 10^{-2}$ & A & NR & [25] \\
\hline rs1568885 & $7.00 \times 10^{-3}$ & $2.10 \times 10^{-2}$ & $\mathrm{TT}$ & NR & [24] \\
\hline rs976881 & $2.00 \times 10^{-3}$ & $2.40 \times 10^{-2}$ & A & NR & [26] \\
\hline rs10210302 & $8.10 \times 10^{-4}$ & $2.67 \times 10^{-2}$ & $\mathrm{CC}$ & $\operatorname{Re}$ & [7] \\
\hline rs1143634 & N.D. & $2.70 \times 10^{-2}$ & $\mathrm{C}$ & NR & [27] \\
\hline rs4645983 & N.D. & $3.00 \times 10^{-2}$ & $\mathrm{TT}$ & $\operatorname{Re}$ & [21] \\
\hline rs2522057 & $2.40 \times 10^{-2}$ & $4.80 \times 10^{-2}$ & $\mathrm{C}$ & NR & [28] \\
\hline rs35260072 & $2.40 \times 10^{-2}$ & $4.80 \times 10^{-2}$ & G & NR & [28] \\
\hline \multicolumn{6}{|c|}{ long-term response } \\
\hline rs1130864 & $4.09 \times 10^{-5}$ & $4.09 \times 10^{-4}$ & $\mathrm{C}$ & $\operatorname{Re}$ & [8] \\
\hline rs9373839 & $1.13 \times 10^{-3}$ & $1.13 \times 10^{-2}$ & $\mathrm{C}$ & $\operatorname{Re}$ & [8] \\
\hline rs1799724 & N.D. & $4.00 \times 10^{-2}$ & $\mathrm{CC}$ & $\operatorname{Re}$ & [29] \\
\hline
\end{tabular}

Adjusted $p$-values not originally reported, but calculated here are represented in italics. NR (allele/genotype frequency higher in nonresponsive patients), Re (allele/genotype frequency higher in responsive patients); N.D. (not defined).

\subsection{Expression Markers—RNA Level}

Our search identified seven publications reporting RNA expression markers ( $4 \times$ on colon mucosa, $3 \times$ on PBMCs) of anti-TNF therapy response in CD patients (Supplementary Table S1). Four of them are based on (three different) genome-wide microarray data [12,30-32]. Additionally, Schmitt et al., 2018 [13] performed RNA-seq on colon mucosa samples, however only after the therapy start, thus these data were omitted from our search. Only one publication reported on long-term predictor of anti-TNF response [33]. In two of the publications, none of the data reached the fold change and/or significance level requested for inclusion in our analysis.

Looking at colon mucosa data, 89 baseline markers of short-term anti-TNF therapy response in CD patients were identified on RNA level ( $\log 2$ fold change in expression between NR and $R e \leq-1.50$ or $\geq+1.50$; adjusted $p<0.05$, Supplementary Table S4); all of them in the same microarray study [12]. Four were confirmed with an alternative method (qRT-PCR, Table 2) but not in an independent cohort of patients [30]. Expression of all but three RNA markers is higher in the NR compared to the Re patients. No baseline RNA predictors of long-term anti-TNF response in colon mucosa were reported thus far. RNA data from blood PBMCs identified five baseline markers of short-term and a single marker of long-term anti-TNF response in CD patients (Table 2). Expression of all but one of the short-term response markers is lower in NR compared to the Re patients, while the long-term response predictor is expressed higher in the NR. None of the blood RNA markers was independently confirmed. 
Table 2. RNA markers linked to anti-TNF response in CD patients.

\begin{tabular}{|c|c|c|c|c|c|}
\hline Gene Name & NCBI Gene ID & $\log 2$ FC NR/Re & $p$-Value & Adjusted $p$-Value & Reference \\
\hline \multicolumn{6}{|c|}{$\begin{array}{c}\text { colon }\left(\text { colon mucosa) }{ }^{1}\right. \\
\text { short-term response }\end{array}$} \\
\hline \multirow{2}{*}{ IL13RA2 } & \multirow{2}{*}{3598} & 2.761 & $1.27 \times 10^{-5}$ & $2.37 \times 10^{-2}$ & [12] \\
\hline & & 2.184 & $<1.00 \times 10^{-2}$ & $<5.00 \times 10^{-2}$ & [30] \\
\hline \multirow{2}{*}{ IL11 } & \multirow{2}{*}{3589} & 3.306 & $1.41 \times 10^{-5}$ & $2.37 \times 10^{-2}$ & {$[12]$} \\
\hline & & 3.184 & $<1.00 \times 10^{-2}$ & $<5.00 \times 10^{-2}$ & [30] \\
\hline \multirow{2}{*}{ STC1 } & \multirow[b]{2}{*}{6781} & 1.514 & $7.49 \times 10^{-5}$ & $3.89 \times 10^{-2}$ & {$[12]$} \\
\hline & & 2.396 & $<1.00 \times 10^{-2}$ & $<5.00 \times 10^{-2}$ & [30] \\
\hline \multirow{2}{*}{ PTGS2 } & \multirow[b]{2}{*}{5743} & 2.206 & $8.55 \times 10^{-5}$ & $3.94 \times 10^{-2}$ & {$[12]$} \\
\hline & & 3.059 & $<1.00 \times 10^{-2}$ & $<5.00 \times 10^{-2}$ & [30] \\
\hline \multicolumn{6}{|c|}{ blood (PBMCs) } \\
\hline \multicolumn{6}{|c|}{ short-term response } \\
\hline DEFA1 & 1667 & -1.885 & $6.72 \times 10^{-3}$ & $9.13 \times 10^{-1}$ & [32] \\
\hline DEFA3 & 1668 & -1.885 & $6.72 \times 10^{-3}$ & $9.13 \times 10^{-1}$ & [32] \\
\hline DEFA1B & 728358 & -1.950 & $6.84 \times 10^{-3}$ & $9.13 \times 10^{-1}$ & [32] \\
\hline SCARNA4 & 677771 & 1.701 & $2.24 \times 10^{-2}$ & $8.96 \times 10^{-1}$ & [31] \\
\hline TMEM176A & 55365 & -1.712 & $2.36 \times 10^{-2}$ & $8.96 \times 10^{-1}$ & [31] \\
\hline \multicolumn{6}{|c|}{ long-term response } \\
\hline TREM1 & 54210 & 2.341 & $2.00 \times 10^{-2}$ & $2.00 \times 10^{-2}$ & [33] \\
\hline
\end{tabular}

\subsection{Expression Markers-Protein Level}

We identified 27 publications reporting baseline protein markers of anti-TNF response in CD patients (Supplementary Table S1). Majority (22 publications) investigated/reported serum markers and markers connected to short-term therapy response (23 publications). Seven studies reported protein markers in colon (four colon mucosa markers, three stool markers). None of the studies reported protein markers on PBMCs. Nine studies reported only negative results, and in an additional four studies the differences observed did not reach our inclusion criteria.

Only two protein markers measured in colon (colon mucosa or stool) fulfilled our inclusion criteria (fold change in expression between NR and $\operatorname{Re} \leq 0.66$ or $\geq 1.50 ; p<0.05$, Table 3 ) and both are connected to short-term therapy response. Calprotectin has multiple independent confirmations. Its baseline expression is higher in NR than in Re patients. Colon mucosa expression of TNF at baseline is lower in NR than in Re. In blood (serum) six protein markers were identified in connection to the short-term therapy response and two with long-term therapy response (Table 3). Among the short-term response markers, four have higher expression in NR than in Re patients at baseline (IL-8, IL-17A, TGF- $\beta 1$ and TNF) while one (IL-15) has a lower expression. The results on the only short-term response serum marker with multiple independent confirmations (CRP) are ambiguous-its baseline expression was lower in NR patients than in Re patients in two studies [34,35] while in the other two studies [36,37] it was higher. Baseline expression of both long-term response serum markers was higher in NR compared to Re patients. 
Table 3. Protein markers linked to anti-TNF response in CD patients [38-46].

\begin{tabular}{|c|c|c|c|}
\hline Protein Name & FC NR/Re & $p$-Value & Reference \\
\hline \multicolumn{4}{|c|}{$\begin{array}{c}\text { colon (colon mucosa, stool) } \\
\text { short-term response } \\
\text { colon mucosa }\end{array}$} \\
\hline \multicolumn{3}{|c|}{ stool } & [40] \\
\hline & 3.053 & $<5.00 \times 10^{-3}$ & [38] \\
\hline calprotectin & 13.889 & $<5.00 \times 10^{-3}$ & [39] \\
\hline & 4.463 & $3.00 \times 10^{-2}$ & [37] \\
\hline \multicolumn{4}{|c|}{ blood (serum) } \\
\hline TGF- $\beta 1$ & 1.724 & $<5.00 \times 10^{-3}$ & {$[44]$} \\
\hline \multirow{4}{*}{ CRP } & 0.571 & $2.00 \times 10^{-2}$ & [34] \\
\hline & 0.568 & $7.00 \times 10^{-3}$ & {$[35]$} \\
\hline & 2.732 & $1.50 \times 10^{-2}$ & [36] \\
\hline & 4.563 & $4.00 \times 10^{-2}$ & [37] \\
\hline IL-8 (CXCL8) & 1.786 & $1.00 \times 10^{-2}$ & [41] \\
\hline IL-15 & 0.054 & $1.00 \times 10^{-2}$ & {$[42]$} \\
\hline TNF & 14.286 & $3.50 \times 10^{-2}$ & {$[45]$} \\
\hline IL-17A & 19.231 & $4.00 \times 10^{-2}$ & [43] \\
\hline \multicolumn{4}{|c|}{ long-term response } \\
\hline TREM1 & 2.096 & $1.00 \times 10^{-3}$ & [33] \\
\hline IL-6 & 1.961 & $2.90 \times 10^{-2}$ & [46] \\
\hline
\end{tabular}

Protein markers with more than one independent confirmation are represented in bold.

\subsection{Integrated Data on Genomic and Expression Markers}

Next, we integrated the collected data on genomic and expression (RNA and protein) markers of anti-TNF therapy response in CD patients. Genes connected to individual SNPs or corresponding to individual RNA and proteins were chosen as common denominators. Genomic markers (SNPs) were integrated via tissue-specific eQTL information. All the genes connected to specific SNPs via eQTL were designated the same $p$-values. RNA and protein names were directly translated into corresponding gene names. In case of complex proteins, all the subunits were taken into account with the same fold change and $p$-value as the original complex protein. In that way we created four lists of integrated data on anti-TNF response markers-for colonic short- and long-term response markers and for short- and long-term response blood markers (Supplementary Tables S5-S8).

Among integrated colonic markers of short-term response, nine have multiple independent confirmations-three of them (FCGR2C, S100A8 and S100A9) on multiple levels of expression (Table 4). The other six (AC034220.3, ACSL6, CASP9, HSPA7, SLC22A4 and SLC22A5) have multiple independent confirmations only on the level of DNA, either as individual SNPs connected (via eQTL) to single genes, multiple SNPs connected to the same gene or individual SNPs connected to multiple genes. In this integration, only one colonic marker of long-term response (CCHCR1) has an independent confirmation (two different SNPs corresponding to the same gene). Integration of blood markers resulted in four short-term response markers with multiple independent confirmations- three (AC116366.6, RPS23P10 and SLC22A5) at the level of DNA and one (CRP) at the protein level (Table 4). None has confirmations on multiple levels of expression. The single blood marker of long-term response (TREM1) has confirmation of two levels of expression (RNA, protein), albeit from the same patient cohort [33]. 
Table 4. Independently confirmed integrated markers linked to anti-TNF response in CD patients.

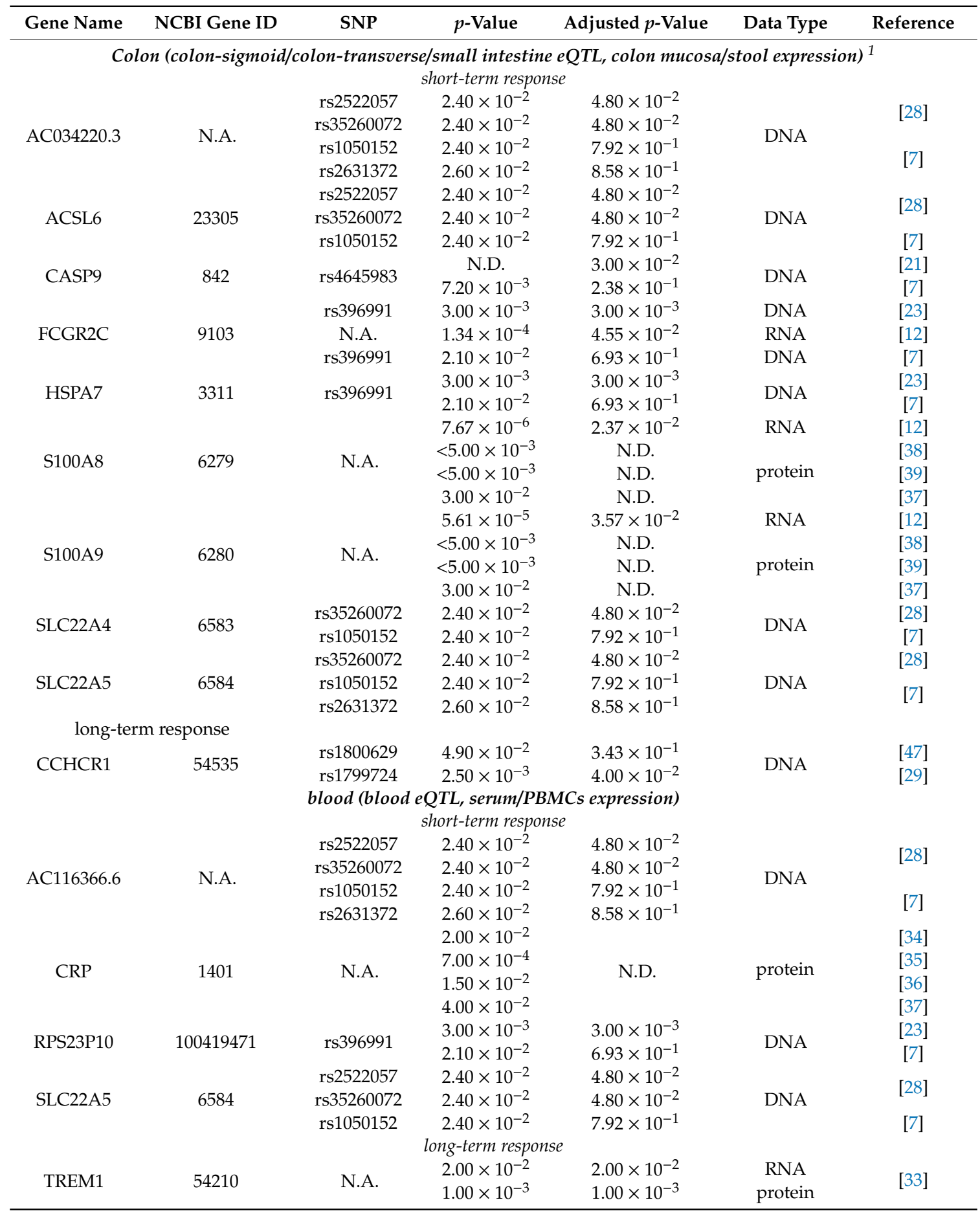

Adjusted $p$-values not originally reported, but calculated here are represented in italics. N.A. (not applicable), N.D. (not defined).

\subsection{Interactomes and Gene Ontology of Anti-TNF Therapy Response Markers}

To check whether the identified response markers interact with each other and thus build common biological pathways we built interactomes of the integrated colonic and blood, short- and long-term response markers, using protein-protein interaction data available at BioGrid (see Methods). The markers which are not translated into proteins were omitted from this analysis. As it soon became clear that almost none of the identified response markers interact to each other (Figures 2 
and 3, Supplementary Figures S1-S5), we subsequently included also their "first neighbours" or "interactors"- proteins interacting directly to the response markers-which significantly improved the connectivity of the individual markers. Further, we used GO analysis to determine biological pathways that are common to the integrated response markers.

\subsubsection{Response Markers of the Colon}

The 109 colonic short-term response markers form eight small networks of two to four individual markers (all together 14 marker-to-marker interactions), while the bulk (88) of these markers are not interacting directly (Supplementary Figure S1). When also markers' first interactors are included we get an interactome of 369 proteins with 655 interactions. The majority (77/109) of the markers and their interactors form a single network, while the rest remain separated from it (Supplementary Figure S2). The 28 colonic short-term response markers remain disconnected from all other also in this broadened interactome. GO analysis of the colonic short-term response markers revealed 47 enriched GO terms (Supplementary Table S9). The most significant were cytokine activity (adjusted $p<5.43 \times 10-5$ ) and chemotaxis (adjusted $p<1.73 \times 10^{-4}$ ). Analysis of the extended interactome revealed 429 enriched GO terms (Supplementary Table S10), with apoptotic process and regulation of response to stimulus as the most significant two (adjusted $p<1.84 \times 10^{-23}$ and $<7.52 \times 10^{-22}$, respectively). Neither of the two GO analyses revealed any underrepresented GO terms.

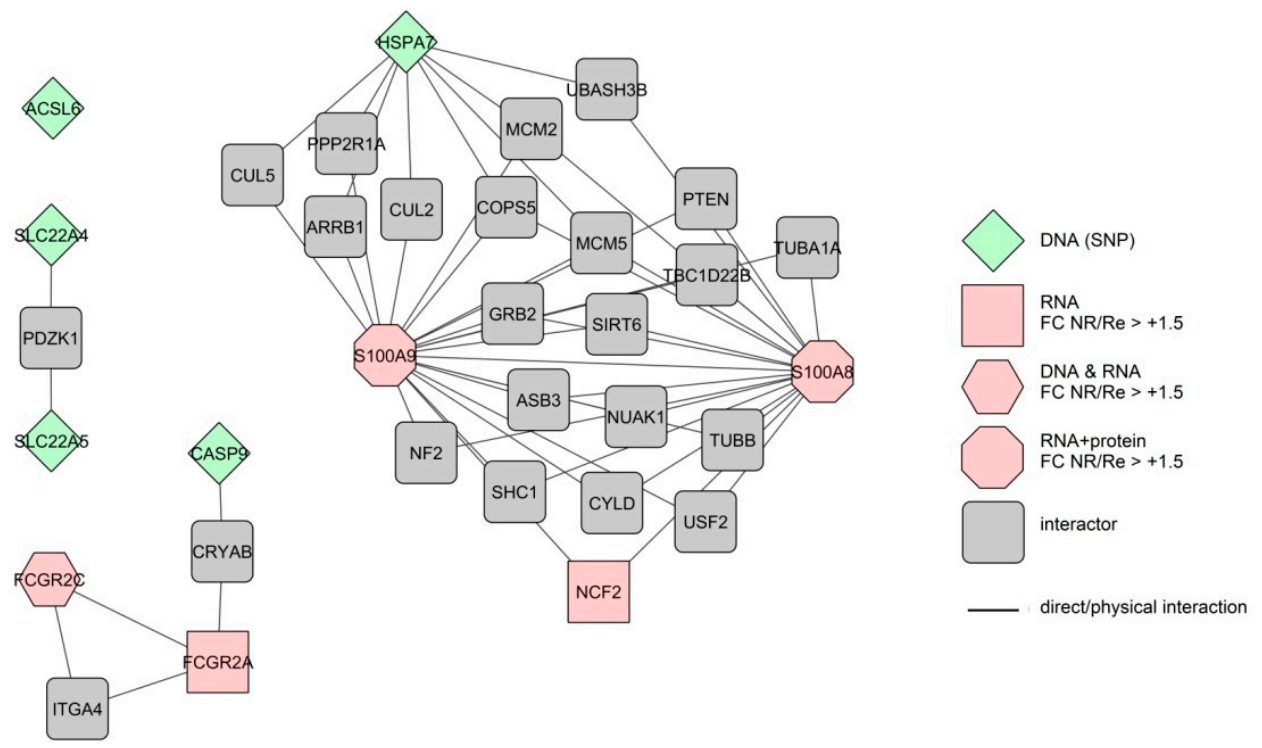

Figure 2. Extended interactome of the independently confirmed, integrated colonic markers linked to the short-term anti-TNF therapy response in CD patients. Different forms represent markers measured at different levels of expression. The colours represent differences in expression level (FC—fold change) between therapy nonresponders (NR) and responders (Re). Lines represent direct protein-protein interactions.

We also built an interactome of colonic short-term response markers with multiple confirmations. Only two (S100A8 and S100A9) of the nine markers interacted directly (Figure 2). Together with their first interactors, the extended interactome consists of 33 proteins with 53 interactions. The interactions here form three separate networks with one marker remaining completely disconnected. GO analysis of the markers alone finds three GO terms (Table 5) and analysis of the extended interactome 15 GO terms. 
Table 5. GO analysis of the independently confirmed, integrated colonic markers linked to the short-term anti-TNF therapy response in CD patients.

\begin{tabular}{|c|c|c|c|c|c|c|}
\hline GO ID & GO Term & $\begin{array}{l}\text { Ontology } \\
\text { Source }\end{array}$ & $p$-Value & $\begin{array}{l}\text { Adjusted } \\
p \text {-Value }\end{array}$ & $\begin{array}{l}\text { \% Assoc. } \\
\text { Genes }\end{array}$ & Genes \\
\hline \multicolumn{7}{|c|}{ GO analysis of the markers } \\
\hline GO:0015909 & long-chain fatty acid transport & BP & $4.28 \times 10^{-6}$ & $4.28 \times 10^{-6}$ & 3.53 & $\begin{array}{l}\text { ACSL6, S100A8, } \\
\quad \text { S100A9 }\end{array}$ \\
\hline GO:0030888 & regulation of B cell proliferation & BP & $3.84 \times 10^{-6}$ & $7.69 \times 10^{-6}$ & 3.66 & $\begin{array}{l}\text { FCGR2C, S100A8, } \\
\text { S100A9 }\end{array}$ \\
\hline GO:0043030 & $\begin{array}{l}\text { regulation of macrophage } \\
\text { activation }\end{array}$ & BP & $2.70 \times 10^{-6}$ & $8.11 \times 10^{-6}$ & 4.11 & $\begin{array}{l}\text { FCGR2C, S100A8, } \\
\text { S100A9 }\end{array}$ \\
\hline \multicolumn{7}{|c|}{$G O$ analysis of the extended interactome } \\
\hline GO:0015838 & amino-acid betaine transport & BP & $1.09 \times 10^{-7}$ & $1.53 \times 10^{-6}$ & 60.00 & $\begin{array}{l}\text { PDZK1, SLC22A4, } \\
\quad \text { SLC22A5 }\end{array}$ \\
\hline GO:0015879 & carnitine transport & ВР & $1.09 \times 10^{-7}$ & $1.53 \times 10^{-6}$ & 60.00 & $\begin{array}{l}\text { PDZK1, SLC22A4, } \\
\text { SLC22A5 }\end{array}$ \\
\hline GO:0015697 & $\begin{array}{l}\text { quaternary ammonium } \\
\text { group transport }\end{array}$ & $\mathrm{BP}$ & $3.81 \times 10^{-7}$ & $4.95 \times 10^{-6}$ & 42.86 & $\begin{array}{l}\text { PDZK1, SLC22A4, } \\
\quad \text { SLC22A5 }\end{array}$ \\
\hline GO:0015695 & organic cation transport & BP & $3.92 \times 10^{-6}$ & $4.70 \times 10^{-5}$ & 21.43 & $\begin{array}{l}\text { PDZK1, SLC22A4, } \\
\quad \text { SLC22A5 }\end{array}$ \\
\hline GO:0030165 & PDZ domain binding & MF & $8.88 \times 10^{-6}$ & $9.76 \times 10^{-5}$ & 6.90 & $\begin{array}{c}\text { PDZK1, PTEN, } \\
\text { SLC22A4, SLC22A5 }\end{array}$ \\
\hline GO:0072337 & modified amino-acid transport & BP & $1.42 \times 10^{-5}$ & $1.42 \times 10^{-4}$ & 14.29 & $\begin{array}{l}\text { PDZK1, SLC22A4, } \\
\text { SLC22A5 }\end{array}$ \\
\hline GO:0015696 & ammonium transport & BP & $3.84 \times 10^{-5}$ & $3.46 \times 10^{-4}$ & 10.34 & $\begin{array}{l}\text { PDZK1, SLC22A4, } \\
\quad \text { SLC22A5 }\end{array}$ \\
\hline GO:0008180 & COP9 signalosome & $\mathrm{CC}$ & $1.88 \times 10^{-4}$ & $5.64 \times 10^{-4}$ & 6.12 & $\begin{array}{c}\text { COPS5, GRB2, } \\
\text { HSPA7 }\end{array}$ \\
\hline GO:0042770 & $\begin{array}{l}\text { signal transduction in response } \\
\text { to DNA damage }\end{array}$ & $\mathrm{BP}$ & $7.67 \times 10^{-5}$ & $6.13 \times 10^{-4}$ & 4.00 & $\begin{array}{l}\text { CASP9, GRB2, } \\
\text { S100A8, S100A9 }\end{array}$ \\
\hline GO:0001540 & amyloid-beta binding & MF & $9.47 \times 10^{-5}$ & $6.63 \times 10^{-4}$ & 7.69 & $\begin{array}{l}\text { CRYAB, FCGR2A, } \\
\text { FCGR2C }\end{array}$ \\
\hline GO:0006898 & receptor-mediated endocytosis & $\mathrm{BP}$ & $1.88 \times 10^{-4}$ & $7.51 \times 10^{-4}$ & 3.17 & $\begin{array}{l}\text { ARRB1, FCGR2A, } \\
\text { FCGR2C, GRB2 }\end{array}$ \\
\hline GO:0090342 & regulation of cell aging & BP & $1.36 \times 10^{-4}$ & $8.17 \times 10^{-4}$ & 6.82 & $\begin{array}{l}\text { NUAK1, S100A8, } \\
\text { S100A9 }\end{array}$ \\
\hline GO:2001235 & $\begin{array}{l}\text { positive regulation of apoptotic } \\
\text { signalling pathway }\end{array}$ & $\mathrm{BP}$ & $1.71 \times 10^{-4}$ & $8.55 \times 10^{-4}$ & 3.25 & $\begin{array}{l}\text { CYLD, PTEN, } \\
\text { S100A8, S100A9 }\end{array}$ \\
\hline GO:0007569 & cell aging & BP & $1.12 \times 10^{-3}$ & $1.12 \times 10^{-3}$ & 3.33 & $\begin{array}{l}\text { NUAK1, S100A8, } \\
\quad \text { S100A9 }\end{array}$ \\
\hline GO:0008630 & $\begin{array}{l}\text { intrinsic apoptotic signalling } \\
\text { pathway in response to } \\
\text { DNA damage }\end{array}$ & BP & $6.61 \times 10^{-4}$ & $1.32 \times 10^{-3}$ & 4.00 & $\begin{array}{l}\text { CASP9, S100A8 } \\
\quad \text { S100A9 }\end{array}$ \\
\hline
\end{tabular}

MF (molecular function), BP (biological process), CC (cellular component).

None of the 14 colonic long-term response markers interact with each other. When their interactors are included in the interactome (all together 42 proteins and 59 interactions) they form a single network, with five markers remaining completely unattached (Supplementary Figure S3). GO analysis of long-term markers alone returned no results, while analysis of the extended interactome returned six enriched GO terms (Supplementary Table S11).

\subsubsection{Response Markers of the Blood}

Short-term response markers identified in blood (40 proteins) form three small groups of two to three members (altogether four interactions) while a majority (33/40) of the markers do not interact (Figure 3). In the extended interactome including their first interactors (184 proteins, 329 interactions) almost all of the markers belong to the same network, with six markers unattached to it (Supplementary Figure S4). 

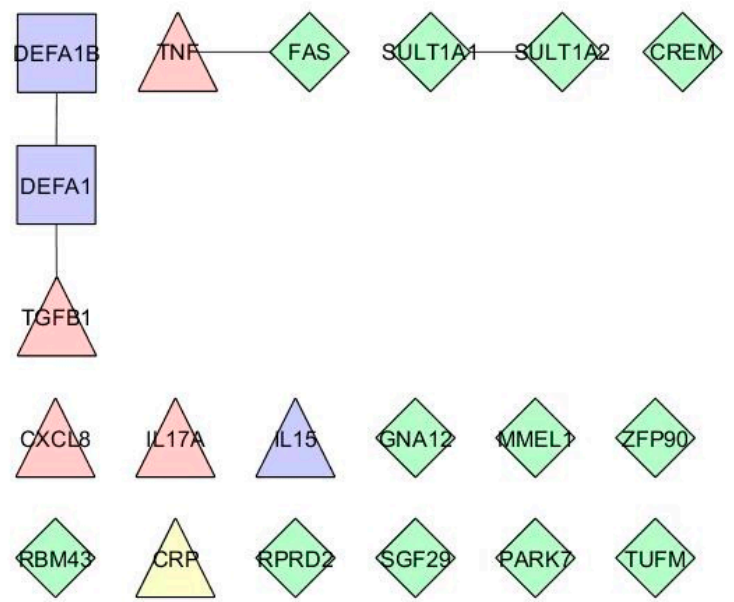

DEFA3
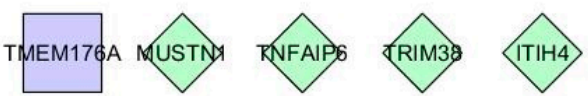

18RA)
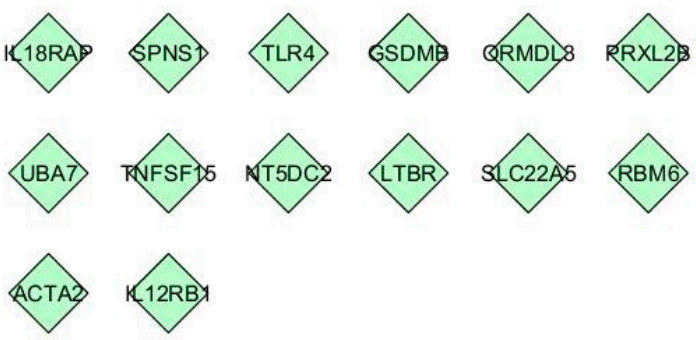

Figure 3. Interactome of the integrated blood markers linked to the short-term anti-TNF therapy response in CD patients. Different forms represent markers measured at different levels of expression. The colours represent differences in expression level (FC-fold change) between therapy nonresponders (NR) and responders (Re). Lines represent direct protein-protein interactions.

GO analysis of the blood short-term response markers returned 18 enriched GO terms (Table 6). The most significant ones are regulation of superoxide metabolic process (adjusted $p<2.48 \times 10^{-8}$ ) and response to steroid hormone (adjusted $p<4.88 \times 10^{-8}$ ). When the extended interactome was analysed, the result was enriched 249 GO terms (Supplementary Table S12). The two blood short-term response markers with multiple confirmations which can be translated into protein (CRP, SLC22A5) do not interact and also do not have common first interactors. GO analysis of the two terms also returned no results.

The 18 long-term response markers identified in blood do not interact directly. In the extended interactome including their first interactors (together 55 proteins, 82 interactions) they form a single network, with six markers remaining unattached to it (Supplementary Figure S5). GO analysis of markers alone returned no results, while analysis of the extended interactome revealed 11 enriched GO terms (Supplementary Table S13). 
Table 6. GO analysis of the integrated blood markers linked to the short-term anti-TNF therapy response in $\mathrm{CD}$ patients.

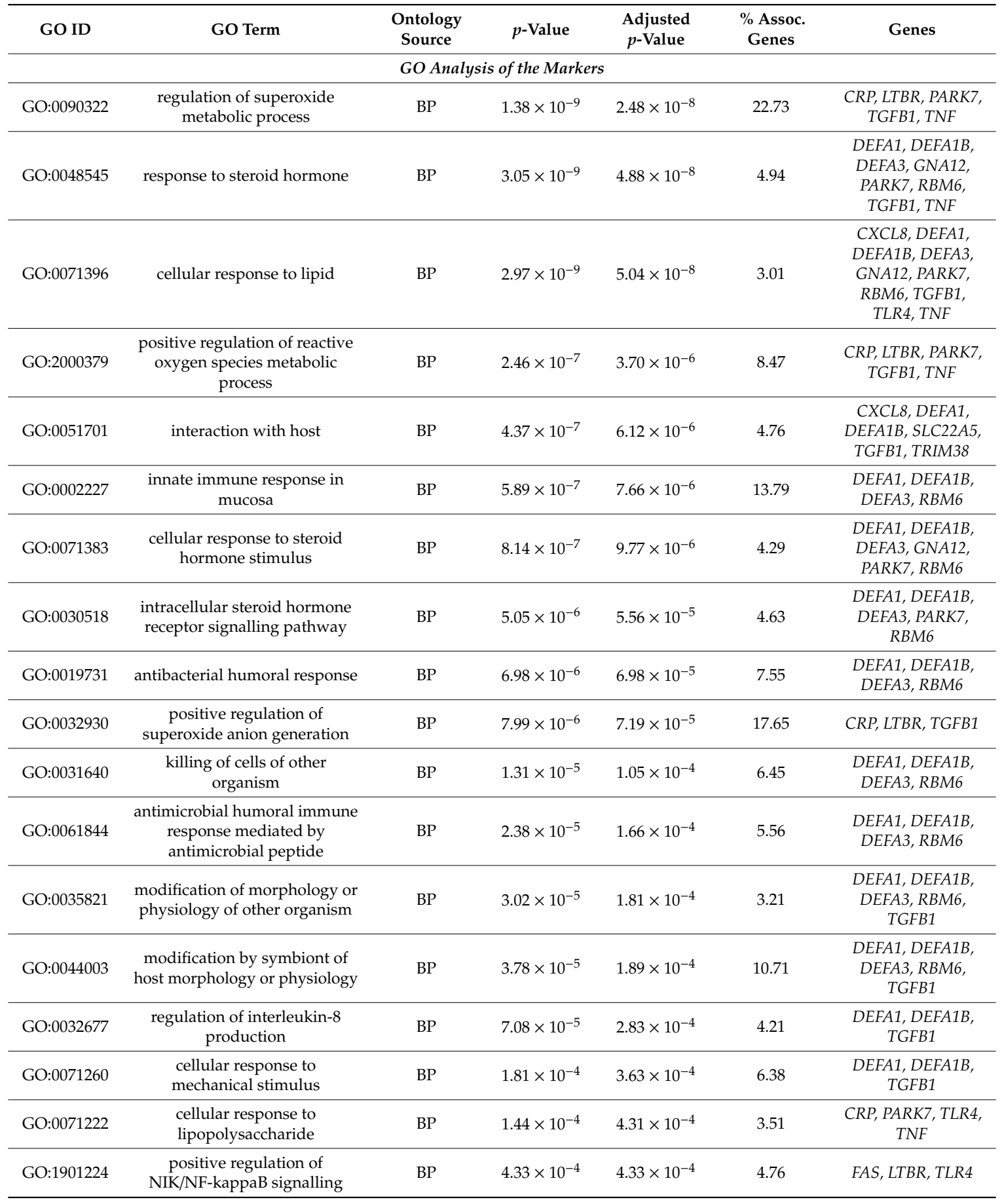

$\mathrm{BP}$ (biological process).

\section{Discussion}

Genomic and expression markers of anti-TNF failure in CD patients are the topic of several recent reviews [16-20]. However, here, for the first time we merge these potential biomarkers from different levels of expression into common interaction networks and analyse the networks with gene ontology tools, aiming at finding common biological pathways behind the therapy non-response.

To identify the candidate genomic and expression predictors of anti-TNF response in CD we systematically screened the published data. We focused on markers that could predict response to 
therapy at baseline, prior to its start. In this regard, use of genomic markers seems the most logical one. DNA can be studied on easily obtainable material (i.e., blood, sputum, stool) prior to treatment, with no need for highly invasive procedures such as colonoscopy and recovery of colon mucosa samples. Additionally, DNA does not change over time or vary between tissues and cell types. We identified 40 studies trying to connect DNA sequence variability, i.e., SNPs to anti-TNF response in CD patients. Their success, however, was quite limited. So far, none of the SNPs proposed as genetic markers of anti-TNF response in CD reached the level of significance demanded for a genome-wide association study $\left(p \leq 5.0 \times 10^{-8}\right)$. Actually, only four SNPs, connected to short-term anti-TNF response in CD were confirmed in multiple independent patient cohorts, none, if $p$-values are adjusted for multiple testing. The reasons for such a poor output may be manifold. First, lack of reproducibility may be due to the limited selection of SNPs included in individual studies. Only three $[10,11,48]$ looked at a larger array ( $>90.000)$ of loci, while the rest focused on a limited subset of genes, such as apoptotic genes [21], NFKB pathway [49], IBD-associated loci [7], or even just a couple of loci/SNPs. In fact, only $\sim 10 \%$ of the SNPs were included in more than one study (data not shown). Next, most of the studies include relatively small numbers of cases (typically 100-300 patients, Supplementary Table S1) and thus lack statistical power needed to reach the high significance levels demanded for a genome-wide association [50]. To amend this, probably a big multi-centre effort similar to the one finding the 163 IBD susceptibility loci [1] is needed.

Unlike in genomic studies, the time-point of data collection is important in expression studies. Since therapy itself changes the expression profiles in patients [51,52], and our focus were pre-treatment predictors of therapy response, we excluded all the data collected post anti-TNF treatment induction. Contrary to the genomic studies, RNA expression studies of anti-TNF response markers in CD are few, but several are genome-wide $[12,13,31,32,52,53]$ and thus less biased than currently published genomic studies. Surprisingly, despite genome-wide screens, there are no independently confirmed baseline RNA markers of anti-TNF response in CD patients. In fact, we had to lower our originally intended criteria for data inclusion ( $\log 2$ FC NR/Re from $\geq 2.00$ to $\geq 1.50$ ) in order to get any hits at all with the PBMCs. Additionally, we had to lower also significance limit for PBMCs $(p<0.05$ instead of adjusted $p<0.05$ ).

Studies reporting protein markers are more numerous than the RNA studies, though most report only data on a few serum proteins (CRP, albumin, haemoglobin) or faecal calprotectin. Some measured several (7-12) serum proteins [41-43,45,54] but so far there are no published baseline proteome-wide studies on the anti-TNF response markers. Many reported results are negative or the differences observed are marginal and would not allow for a robust cut-off for practical use. The majority of the protein markers also lack independent confirmation. The two protein markers with multiple independent confirmations are serum CRP and faecal calprotectin. Both are nowadays readily measured in $\mathrm{CD} / \mathrm{IBD}$ patients to assess therapy effectiveness post-induction and are being assessed also as baseline response predictors [37]. While high baseline faecal calprotectin seems to be predictive of therapy failure, there is so far no unified cut-off value for practical use. The proposed cut-offs vary widely, from $160 \mu \mathrm{g} / \mathrm{g}$ to $863 \mu \mathrm{g} / \mathrm{g}$ [37-39]. On the other hand, data on baseline serum CRP are so far inconclusive; although several studies confirm differential baseline CRP expression between NR and Re patients, the direction of this difference varies between studies (see Table 3, [20]).

Altogether, as with SNPs, poor reproducibility is a problem also with expression biomarkers of anti-TNF response in CD. Additionally, as with SNPs, lack of "whole genome" studies (at least at protein level) and low numbers of included patients (RNA level, Supplementary Table S1) may be reasons for this. Additionally, gene expression reflects the processes in the patient and is influenced by environmental factors. For example, patient cohorts from selected studies include anti-TNF naïve patients, patients already switched from another anti-TNF drug, and practically all of them had additional therapies prior and/or concomitant to anti-TNF induction.

A possible solution for poor reproducibility of results on individual levels of expression (DNA, RNA, protein) is integration of data from different levels. However, it also poses an additional problem, 
namely, how to connect data on SNPs with expression data. For the purpose of this review, genes connected to individual SNPs or corresponding to individual RNA/proteins were chosen as common denominators. We used publicly available tissue-specific eQTL data to annotate SNPs to specific genes. In several cases that meant that the connection is not the same as was intended in the original reference. For example, many studies focused on SNPs in or near the TNF gene [22,27,34,55-57] however current eQTL data do not confirm connection between these SNPs and the TNF gene. Additionally, while for example rs10210302 is clearly connected to ATG16L1 expression in skin, thyroid or subcutaneous adipose tissue, there is no eQTL data connecting the SNP to the ATG16L1 expression in colon or blood. On the other hand, it turned out that several SNPs that were detected as potential biomarkers in only single studies influence the same gene and thus do have some sort of independent confirmation (Table 4). Another entity difficult to compare to other levels of expression, complex proteins, we dissected to their subunits (for example calprotectin to S100-A8 and S100-A9) and designated the fold changes and $p$-values of the whole protein to all the subunits. Using this approach, out of identified 108 genomic, 95 RNA and 10 protein markers we created a selection of 15 markers with multiple confirmations. Although the total number of baseline markers with multiple confirmations more than doubled compared to the individual level comparisons, it is difficult not to observe that there is no repeatability between genomic and expression markers. Only FCGR2C was detected both at genomic and expression (RNA) level.

To determine whether the identified markers at least belong to the same biological processes and pathways we build interactomes (extra for colon and blood markers, short- and long-term response markers) based on publicly available protein-protein interaction data and performed GO analysis of these interactomes. Similar approaches were used for IBD in general to build interactomes of genes annotated from SNPs without use of tissue-specific eQTL data [11], baseline blood expression markers [32] and post-baseline colon expression markers [52] connected to anti-TNF response. In our CD-oriented study, it soon became clear that there are almost no direct interactions between the identified response markers, so we introduced into the networks also proteins, with which the markers directly interact. Such approach can lead to better insight into complex connections when limited data on direct interactions between proteins of interest are available [58]. In that way, almost all markers for short-term response are connected into common networks of interactions. On the contrary, only $2 / 3$ of the long-term response markers are connected in common networks. This is reflected also in the GO analysis. Analysis of both marker sets (colon, blood) returned no results, while analysis of the extended interactomes resulted in very unspecific terms connected to degradation of faulty proteins, response to UV light and cytoskeleton organization.

The most significantly enriched GO terms for the short-term response markers in colon were connected with cytokine activity and immune response, chemotaxis and leukocyte migration-in general inflammation. The GO analysis of blood short-term response markers resulted in enriched GO terms connected to ROS (Reactive Oxygen Species) response, steroid hormone response and immune response. Looking at both extended interactomes (with direct interactors of markers) apoptosis-response to reactive oxygen species (ROS) - and general terms linked to signalling- and protein-metabolism are also enriched.

While the increased colon inflammation despite anti-TNF treatment is quite literally the definition of non-response, pre-treatment disease severity in general is not predictable of anti-TNF response in CD [4]. This in a way is counterintuitive, as faecal calprotectin, a marker of inflammation in the gut [59] is under consideration as a baseline therapy response predictor, as already mentioned above. Since our GO analyses show calprotectin (S100A8/9) connection to several GO terms not directly associated to inflammation (see Table 5) it is possible that predictive value of calprotectin originates from one of them, as is discussed below. Differences in cytokine signalling were suggested also by Gaujoux et al., 2018 [32] based on their GO analysis of baseline blood RNA markers. However, several studies measuring whole arrays of serum cytokines on protein levels found differences between NR and Re only in individual interleukins (IL-8 [41], IL-15 [42], IL-17A [43], TNF [45]). A recent study that measured 
baseline protein levels of several cytokines in colon mucosa also found no differences [13]. Connection between anti-TNF loss of response and ROS response was also suggested in a post-treatment study of expression markers in colon [60]; however, measurements of the actual ROS in baseline serum of the NR and Re patients did not find any difference between the two groups [61]. It is possible that the "potential" differences in inflammation, cytokine and ROS responses between the NR and Re patients become relevant only after the therapy start. Indeed, the majority of the ROS response associated genes identified in our analysis (TNF, TGFB1, PARK7, LTBR) are also among the genes connected to apoptotic process, which according to our GO analyses is strongly associated with non-response to anti-TNF in both colon and blood (Supplementary Tables S10 and S12, individual genes not shown). Apoptosis is at the centre of so far the most comprehensive (post-treatment induction) model of anti-TNF non-response in CD [13]. In the model, failure of the CD4+ T-cells to undergo apoptosis leads to increased inflammation, meaning that the potential baseline difference in inflammation response as suggested by our GO analysis becomes relevant. Among the key players of the Schmitt et al. model (TNF, TNFR2, STAT3, IL23A, IL23R) [13] our screen for baseline therapy response predictors detected only TNF, further underlining that sets of baseline response predictors and post-therapy response markers can differ significantly despite belonging to the same signalling pathways (GO terms). The anti-apoptotic effect on T-cells in the model is augmented by macrophages; and regulation of macrophage activation via FCGR2C (low affinity IgG receptor) and calprotectin (S100A8/9) is indeed enhanced in NR already at baseline, as suggested by our GO analysis of the colon biomarkers with multiple independent confirmations (Table 5, Figure 1).

\section{Conclusions}

In conclusion, currently genomic markers of anti-TNF response in $\mathrm{CD}$ patients are not reaching sufficient significance levels and there is practically no reproducibility between genomic and baseline expression markers. To amend this, whole-genomes transcriptomes and/or proteomes should be measured in the same individuals. We and others [62] are already creating appropriate biobanks of patients' samples; however, multinational efforts to create larger patient cohorts will be needed if we are to reach also the sufficient statistical power of data. For now, GO analysis indicates that pre-treatment differences in apoptosis, ROS and inflammation response between nonresponders and responders to anti-TNF therapy be should thoroughly researched for potential baseline biomarkers.

Supplementary Materials: The following files are available online at http://www.mdpi.com/2073-4409/8/6/515/ s1 [63-88]. Supplementary Methods, Supplementary Figure S1. Interactome of the integrated colon markers linked to the short-term anti-TNF therapy response in CD patients, Supplementary Figure S2. Extended interactome of the integrated colon markers linked to the short-term anti-TNF therapy response in CD patients, Supplementary Figure S3. Extended interactome of the integrated colon markers linked to the long-term anti-TNF therapy response in CD patients, Supplementary Figure S4. Extended interactome of the integrated blood markers linked to the short-term anti-TNF therapy response in CD patients. Supplementary Figure S5. Extended interactome of the integrated blood markers linked to the long-term anti-TNF therapy response in CD patients, Supplementary Tables.

Author Contributions: Conceptualization, B.G. and U.P.; methodology B.G. and U.P.; formal analysis, B.G. investigation, B.G.; data curation, B.G.; writing-original draft preparation, B.G.; writing-review and editing, B.G. and U.P.; visualization, B.G.; supervision, U.P.

Funding: This research was supported by the Slovenian Research Agency (grant J3-9258 “Molecular genetic biomarkers and mechanisms of unresponsiveness to biological therapy anti-TNF in patients with chronic immune diseases" awarded to U.P.)

Conflicts of Interest: The authors declare no conflicts of interest.

\section{References}

1. Jostins, L.; Ripke, S.; Weersma, R.K.; Duerr, R.H.; McGovern, D.P.; Hui, K.Y.; Lee, J.C.; Schumm, L.P.; Sharma, Y.; Anderson, C.A.; et al. Host-microbe interactions have shaped the genetic architecture of inflammatory bowel disease. Nat. Cell Boil. 2012, 491, 119-124. [CrossRef] [PubMed] 
2. Linares-Pineda, T.M.; Cañadas-Garre, M.; Sánchez-Pozo, A.; Calleja-Hernández, M.Á. Pharmacogenetic biomarkers of response in Crohn's disease. Pharm. J. 2017, 8, 1-13. [CrossRef] [PubMed]

3. Cohn, H.M.; Dave, M.; Loftus, E.V., Jr. Understanding the Cautions and Contraindications of Immunomodulator and Biologic Therapies for Use in Inflammatory Bowel Disease. Inflamm. Bowel Dis. 2017, 23, 1301-1315. [CrossRef] [PubMed]

4. Lopetuso, L.R.; Gerardi, V.; Papa, V.; Scaldaferri, F.; Rapaccini, G.L.; Gasbarrini, A.; Papa, A. Can We Predict the Efficacy of Anti-TNF- $\alpha$ Agents? Int. J. Mol. Sci. 2017, 18, 1973. [CrossRef] [PubMed]

5. Qiu, Y.; Chen, B.L.; Mao, R.; Zhang, S.H.; He, Y.; Zeng, Z.R.; Ben-Horin, S.; Chen, M.H. Systematic review with meta-analysis: Loss of response and requirement of anti-TNF $\alpha$ dose intensification in Crohn's disease. J. Gastroenterol. 2017, 52, 535-554. [CrossRef] [PubMed]

6. Reinglas, J.; Gonczi, L.; Kurt, Z.; Bessissow, T.; Lakatos, P.L. Positioning of old and new biologicals and small molecules in the treatment of inflammatory bowel diseases. World J. Gastroenterol. 2018, 24, 3567-3582. [CrossRef] [PubMed]

7. Koder, S.; Repnik, K.; Ferkolj, I.; Pernat, C.; Skok, P.; Weersma, R.K.; Potočnik, U. Genetic polymorphism in ATG16L1 gene influences the response to adalimumab in Crohn's disease patients. Pharmacogenomics 2015, 16, 191-204. [CrossRef]

8. Deželak, M.; Repnik, K.; Koder, S.; Ferkolj, I.; Potočnik, U. A Prospective Pharmacogenomic Study of Crohn's Disease Patients during Routine Therapy with Anti-TNF- $\alpha$ Drug Adalimumab: Contribution of ATG5, NFKB1, and CRP Genes to Pharmacodynamic Variability. Omics: J. Integr. Biol. 2016, 20, 296-309. [CrossRef]

9. Repnik, K.; Koder, S.; Skok, P.; Ferkolj, I.; Potočnik, U. Transferrin Level Before Treatment and Genetic Polymorphism in HFE Gene as Predictive Markers for Response to Adalimumab in Crohn's Disease Patients. Biochem. Genet. 2016, 54, 476-486. [CrossRef]

10. Barber, G.E.; Yajnik, V.; Khalili, H.; Giallourakis, C.; Garber, J.; Xavier, R.; Ananthakrishnan, A.N. Genetic markers predict primary non-response and durable response to anti-TNF biologic therapies in Crohn's disease. Am. J. Gastroenterol. 2016, 111, 1816-1822. [CrossRef]

11. Yoon, S.M.; Haritunians, T.; Chhina, S.; Liu, Z.; Yang, S.; Landers, C.; Li, D.; Ye, B.D.; Shih, D.; Vasiliauskas, E.A.; et al. Colonic Phenotypes Are Associated with Poorer Response to Anti-TNF Therapies in Patients with IBD. Inflamm. Bowel Dis. 2017, 23, 1382-1393. [CrossRef] [PubMed]

12. Arijs, I.; De Hertogh, G.; Lemaire, K.; Quintens, R.; Van Lommel, L.; Van Steen, K.; Leemans, P.; Cleynen, I.; Van Assche, G.; Vermeire, S.; et al. Mucosal gene expression of antimicrobial peptides in inflammatory bowel disease before and after first infliximab treatment. PLoS ONE 2009, 4, e7984. [CrossRef] [PubMed]

13. Schmitt, H.; Billmeier, U.; Dieterich, W.; Rath, T.; Sonnewald, S.; Reid, S.; Hirschmann, S.; Hildner, K.; Waldner, M.J.; Mudter, J.; et al. Expansion of IL-23 receptor bearing TNFR2+ T cells is associated with molecular resistance to anti-TNF therapy in Crohn's disease. Gut 2019, 68, 814-828. [CrossRef] [PubMed]

14. Andersen, V.; Hansen, A.K.; Heitmann, B.L. Potential Impact of Diet on Treatment Effect from Anti-TNF Drugs in Inflammatory Bowel Disease. Nutrients 2017, 9, 286. [CrossRef] [PubMed]

15. Steenholdt, C. Personalized therapy with TNF-inhibitors in Crohn's disease: Optimizing treatment outcomes by monitoring drug levels and anti-drug antibodies. Dan. Med. J. 2016, 63, B5270. [PubMed]

16. Bek, S.; Nielsen, J.V.; Bojesen, A.B.; Franke, A.; Bank, S.; Vogel, U.; Andersen, V. Systematic review: Genetic biomarkers associated with anti-TNF treatment response in inflammatory bowel diseases. Aliment. Pharmacol. Ther. 2016, 44, 554-567. [CrossRef]

17. Kopylov, U.; Seidman, E. Predicting durable response or resistance to antitumor necrosis factor therapy in inflammatory bowel disease. Therap. Adv. Gastroenterol. 2016, 9, 513-526. [CrossRef]

18. Prieto-Pérez, R.; Almoguera, B.; Cabaleiro, T.; Hakonarson, H.; Abad-Santos, F. Association between Genetic Polymorphisms and Response to Anti-TNFs in Patients with Inflammatory Bowel Disease. Int. J. Mol. Sci. 2016, 17, 225. [CrossRef]

19. Stevens, T.W.; Matheeuwsen, M.; Lönnkvist, M.H.; Parker, C.E.; Wildenberg, M.E.; Gecse, K.B.; D’Haens, G.R. Systematic review: Predictive biomarkers of therapeutic response in inflammatory bowel disease-personalised medicine in its infancy. Aliment. Pharmacol. Ther. 2018, 48, 1213-1231. [CrossRef]

20. Naviglio, S.; Giuffrida, P.; Stocco, G.; Lenti, M.V.; Ventura, A.; Corazza, G.R.; Di Sabatino, A. How to predict response to anti-tumour necrosis factor agents in inflammatory bowel disease. Expert Rev. Gastroenterol. Hepatol. 2018, 12, 797-810. [CrossRef] 
21. Hlavaty, T.; Pierik, M.; Henckaerts, L.; Ferrante, M.; Joossens, S.; van Schuerbeek, N.; Noman, M.; Rutgeerts, P.; Vermeire, S. Polymorphisms in apoptosis genes predict response to infliximab therapy in luminal and fistulizing Crohn's disease. Aliment. Pharmacol. Ther. 2005, 22, 613-626. [CrossRef] [PubMed]

22. Dideberg, V.; Louis, E.; Farnir, F.; Bertoli, S.; Vermeire, S.; Rutgeerts, P.; De Vos, M.; Van Gossum, A.; Belaiche, J.; Bours, V. Lymphotoxin alpha gene in Crohn's disease patients: Absence of implication in the response to infliximab in a large cohort study. Pharm. Genom. 2006, 16, 369-373. [CrossRef] [PubMed]

23. Louis, E.; El Ghoul, Z.; Vermeire, S.; Dall'Ozzo, S.; Rutgeerts, P.; Paintaud, G.; Belaiche, J.; De Vos, M.; Van Gossum, A.; Colombel, J.F.; et al. Association between polymorphism in IgG Fc receptor IIIa coding gene and biological response to infliximab in Crohn's disease. Aliment. Pharmacol. Ther. 2004, 19, 511-519. [CrossRef] [PubMed]

24. Thomas, D.; Gazouli, M.; Karantanos, T.; Rigoglou, S.; Karamanolis, G.; Bramis, K.; Zografos, G.; E Theodoropoulos, G. Association of rs1568885, rs1813443 and rs4411591 polymorphisms with anti-TNF medication response in Greek patients with Crohn's disease. World J. Gastroenterol. 2014, 20, 3609-3614. [CrossRef] [PubMed]

25. Medrano, L.M.; Taxonera, C.; Márquez, A.; Barreiro-de Acosta, M.; Gómez-García, M.; González-Artacho, C.; Pérez-Calle, J.L.; Bermejo, F.; Lopez-Sanromán, A.; Martín Arranz, M.D.; et al. Role of TNFRSF1B polymorphisms in the response of Crohn's disease patients to infliximab. Hum. Immunol. 2014, 75, 71-75. [CrossRef] [PubMed]

26. Steenholdt, C.; Enevold, C.; Ainsworth, M.A.; Brynskov, J.; Thomsen, O.Ø.; Bendtzen, K. Genetic polymorphisms of tumour necrosis factor receptor superfamily $1 \mathrm{~b}$ and fas ligand are associated with clinical efficacy and/or acute severe infusion reactions to infliximab in Crohn's disease. Aliment. Pharmacol. Ther. 2012, 36, 650-659. [CrossRef] [PubMed]

27. Lacruz-Guzmán, D.; Torres-Moreno, D.; Pedrero, F.; Romero-Cara, P.; García-Tercero, I.; Trujillo-Santos, J.; Conesa-Zamora, P. Influence of polymorphisms and TNF and IL1 $\beta$ serum concentration on the infliximab response in Crohn's disease and ulcerative colitis. Eur. J. Clin. Pharmacol. 2013, 69, 431-438. [CrossRef] [PubMed]

28. Urcelay, E.; Mendoza, J.L.; Martinez, A.; Fernandez, L.; Taxonera, C.; Diaz-Rubio, M.; de la Concha, E.G. IBD5 polymorphisms in inflammatory bowel disease: Association with response to infliximab. World J. Gastroenterol. 2005, 11, 1187-1192. [CrossRef] [PubMed]

29. Matsuoka, K.; Hamada, S.; Shimizu, M.; Nanki, K.; Mizuno, S.; Kiyohara, H.; Arai, M.; Sugimoto, S.; Iwao, Y.; Ogata, H.; et al. Factors predicting the therapeutic response to infliximab during maintenance therapy in Japanese patients with Crohn's disease. PLoS ONE 2018, 13, e0204632. [CrossRef] [PubMed]

30. Arijs, I.; Quintens, R.; Van Lommel, L.; Van Steen, K.; De Hertogh, G.; Lemaire, K.; Schraenen, A.; Perrier, C.; Van Assche, G.; Vermeire, S.; et al. Predictive value of epithelial gene expression profiles for response to infliximab in Crohn's disease. Inflamm. Bowel Dis. 2010, 12, 2090-2098. [CrossRef] [PubMed]

31. Mesko, B.; Poliska, S.; Váncsa, A.; Szekanecz, Z.; Palatka, K.; Hollo, Z.; Horvath, A.; Steiner, L.; Zahuczky, G.; Podani, J.; et al. Peripheral blood derived gene panels predict response to infliximab in rheumatoid arthritis and Crohn's disease. Genome Med. 2013, 5, 59. [CrossRef] [PubMed]

32. Gaujoux, R.; Starosvetsky, E.; Maimon, N.; Vallania, F.; Bar-Yoseph, H.; Pressman, S.; Weisshof, R.; Goren, I.; Rabinowitz, K.; Waterman, M.; et al. Cell-centred meta-analysis reveals baseline predictors of anti-TNF $\alpha$ non-response in biopsy and blood of patients with IBD. Gut 2019, 68, 604-614. [CrossRef] [PubMed]

33. Verstockt, B.; Verstockt, S.; Blevi, H.; Cleynen, I.; De Bruyn, M.; Van Assche, G.; Vermeire, S.; Ferrante, M. TREM-1, the ideal predictive biomarker for endoscopic healing in anti-TNF-treated Crohn's disease patients? Gut 2018. [CrossRef] [PubMed]

34. Louis, E.; Vermeire, S.; Rutgeerts, P.; De Vos, M.; Van Gossum, A.; Pescatore, P.; Fiasse, R.; Pelckmans, P.; Reynaert, H.; D'Haens, G.; et al. Inflammatory Bowel Disease A Positive Response to Infliximab in Crohn Disease: Association with a Higher Systemic Inflammation Before Treatment But Not With -308 TNF Gene Polymorphism. Scand. J. Gastroenterol. 2002, 37, 818-824. [CrossRef] [PubMed]

35. Reinisch, W.; Wang, Y.; Oddens, B.J.; Link, R. C-reactive protein, an indicator for maintained response or remission to infliximab in patients with Crohn's disease: A post-hoc analysis from ACCENT I. Aliment. Pharmacol. Ther. 2012, 35, 568-576. [CrossRef] [PubMed] 
36. Magro, F.; Rodrigues-Pinto, E.; Santos-Antunes, J.; Vilas-Boas, F.; Lopes, S.; Nunes, A.; Camila-Dias, C.; Macedo, G. High C-reactive protein in Crohn's disease patients predicts nonresponse to infliximab treatment. J. Crohn's Colitis 2014, 8, 129-136. [CrossRef] [PubMed]

37. Beltrán, B.; Iborra, M.; Sáez-González, E.; Marqués-Miñana, M.R.; Moret, I.; Cerrillo, E.; Tortosa, L.; Bastida, G.; Hinojosa, J.; Poveda-Andrés, J.L.; et al. Fecal Calprotectin Pretreatment and Induction Infliximab Levels for Prediction of Primary Nonresponse to Infliximab Therapy in Crohn's Disease. Dig. Dis. 2019, 37, 108-115. [CrossRef] [PubMed]

38. Ferreiro-Iglesias, R.; Barreiro-de Acosta, M.; Otero Santiago, M.; Lorenzo Gonzalez, A.; Alonso de la Peña, C.; Benitez Estevez, A.J.; Dominguez-Muñoz, J.E. Fecal Calprotectin as Predictor of Relapse in Patients With Inflammatory Bowel Disease Under Maintenance Infliximab Therapy. J. Clin. Gastroenterol. 2016, 50, 147-151. [CrossRef]

39. Ferreiro-Iglesias, R.; Barreiro-de Acosta, M.; Lorenzo-Gonzalez, A.; Dominguez-Muñoz, J.E. Usefulness of a rapid faecal calprotectin test to predict relapse in Crohn's disease patients on maintenance treatment with adalimumab. Scand. J. Gastroenterol. 2016, 51, 442-447. [CrossRef]

40. Atreya, R.; Neumann, H.; Neufert, C.; Waldner, M.J.; Billmeier, U.; Zopf, Y.; Willma, M.; App, C.; Münster, T.; Kessler, H.; et al. In vivo imaging using fluorescent antibodies to tumor necrosis factor predicts therapeutic response in Crohn's disease. Nat. Med. 2014, 20,313-318. [CrossRef]

41. Billiet, T.; Cleynen, I.; Ballet, V.; Claes, K.; Princen, F.; Singh, S.; Ferrante, M.; Van Assche, G.; Gils, A.; Vermeire, S. Evolution of cytokines and inflammatory biomarkers during infliximab induction therapy and the impact of inflammatory burden on primary response in patients with Crohn's disease. Scand. J. Gastroenterol. 2017, 52, 1086-1092. [CrossRef] [PubMed]

42. Bouchaud, G.; Mortier, E.; Flamant, M.; Barbieux, I.; Plet, A.; Galmiche, J.P.; Jacques, Y.; Bourreille, A. Interleukin-15 and its soluble receptor mediate the response to infliximab in patients with Crohn's disease. Gastroenterology 2010, 138, 2378-2387. [CrossRef] [PubMed]

43. Ogawa, K.; Matsumoto, T.; Esaki, M.; Torisu, T.; Iida, M. Profiles of circulating cytokines in patients with Crohn's disease under maintenance therapy with infliximab. J. Crohn's Colitis 2012, 6, 529-535. [CrossRef] [PubMed]

44. Di Sabatino, A.; Biancheri, P.; Piconese, S.; Rosado, M.M.; Ardizzone, S.; Rovedatti, L.; Ubezio, C.; Massari, A.; Sampietro, G.M.; Foschi, D.; et al. Peripheral regulatory T cells and serum transforming growth factor- $\beta$ : Relationship with clinical response to infliximab in Crohn's disease. Inflamm. Bowel Dis. 2010, 16, 1891-1897. [CrossRef] [PubMed]

45. Martínez-Borra, J.; López-Larrea, C.; González, S.; Fuentes, D.; Dieguez, A.; Deschamps, E.M.; Pérez-Pariente, J.M.; López-Vázquez, A.; de Francisco, R.; Rodrigo, L. High serum tumor necrosis factor-alpha levels are associated with lack of response to infliximab in fistulizing Crohn's disease. Am. J. Gastroenterol. 2002, 97, 2350-2356. [CrossRef]

46. Suzuki, Y.; Matsui, T.; Ito, H.; Ashida, T.; Nakamura, S.; Motoya, S.; Matsumoto, T.; Sato, N.; Ozaki, K.; Watanabe, M.; et al. Circulating Interleukin 6 and Albumin, and Infliximab Levels Are Good Predictors of Recovering Efficacy After Dose Escalation Infliximab Therapy in Patients with Loss of Response to Treatment for Crohn's Disease: A Prospective Clinical Trial. Inflamm. Bowel Dis. 2015, 21, 2114-2122.

47. Netz, U.; Carter, J.V.; Eichenberger, M.R.; Dryden, G.W.; Pan, J.; Rai, S.N.; Galandiuk, S. Genetic polymorphisms predict response to anti-tumor necrosis factor treatment in Crohn's disease. World J. Gastroenterol. 2017, 23, 4958-4967. [CrossRef]

48. Billiet, T.; De Bruyn, M.; Verstockt, B.; Princen, F.; Singh, S.; Ferrante, M.; Papamichael, K.; Cleynen, I.; Van Assche, G.; Vermeire, S. A Matrix-based Model Predicts Primary Response to Infliximab in Crohn's Disease. J. Crohn's Coliti 2015, 9, 1120-1126. [CrossRef]

49. Bank, S.; Andersen, P.S.; Burisch, J.; Pedersen, N.; Roug, S.; Galsgaard, J.; Turino, S.Y.; Brodersen, J.B.; Rashid, S.; Rasmussen, B.K.; et al. Associations between functional polymorphisms in the NFkB signaling pathway and response to anti-TNF treatment in Danish patients with inflammatory bowel disease. Pharm. J. 2014, 14, 526-534. [CrossRef]

50. Hong, E.P.; Park, J.W. Sample size and statistical power calculation in genetic association studies. Genom. Inform. 2012, 10, 117-122. [CrossRef] 
51. Arijs, I.; De Hertogh, G.; Machiels, K.; Van Steen, K.; Lemaire, K.; Schraenen, A.; Van Lommel, L.; Quintens, R.; Van Assche, G.; Vermeire, S.; et al. Mucosal Gene Expression of Cell Adhesion Molecules, Chemokines, and Chemokine Receptors in Patients With Inflammatory Bowel Disease Before and After Infliximab Treatment. Am. J. Gastroenterol. 2011, 106, 748-761. [CrossRef] [PubMed]

52. Leal, R.F.; Planell, N.; Kajekar, R.; Lozano, J.J.; Ordás, I.; Dotti, I.; Esteller, M.; Masamunt, M.C.; Parmar, H.; Panes, J. Identification of inflammatory mediators in patients with Crohn's disease unresponsive to anti-TNF $\alpha$ therapy. Gut 2015, 64, 233-242. [CrossRef]

53. Planell, N.; Masamunt, M.C.; Leal, R.F.; Rodríguez, L.; Esteller, M.; Lozano, J.J.; Ramírez, A.; Ayrizono, M.D.L.S.; Coy, C.S.R.; Alfaro, I.; et al. Usefulness of Transcriptional Blood Biomarkers as a Non-invasive Surrogate Marker of Mucosal Healing and Endoscopic Response in Ulcerative Colitis. J. Crohn's Coliti 2017, 11, 1335-1346. [CrossRef] [PubMed]

54. Sandahl, T.D.; Kelsen, J.; Dige, A.; Dahlerup, J.F.; Agnholt, J.; Hvas, C.L.; Thiel, S. The lectin pathway of the complement system is downregulated in Crohn's disease patients who respond to anti-TNF- $\alpha$ therapy. J. Crohn's Colitis 2014, 8, 521-528. [CrossRef]

55. Taylor, K.D.; Plevy, S.E.; Yang, H.; Landers, C.J.; Barry, M.J.; Rotter, J.I.; Targan, S.R. ANCA pattern and LTA haplotype relationship to clinical responses to anti-TNF antibody treatment in Crohn's disease. Gastroenterology 2001, 120, 1347-1355. [CrossRef] [PubMed]

56. Papamichael, K.; Gazouli, M.; Karakoidas, C.; Panayotou, I.; Roma-Giannikou, E.; Mantzaris, G.J. Association of TNF and Fc $\gamma$ RIIIA gene polymorphisms with differential response to infliximab in a Greek cohort of Crohn's disease patients. Ann. Gastroenterol. 2011, 24, 35-40. [PubMed]

57. Mascheretti, S.; Hampe, J.; Kühbacher, T.; Herfarth, H.; Krawczak, M.; Fölsch, U.R.; Schreiber, S. Pharmacogenetic investigation of the TNF/TNF-receptor system in patients with chronic active Crohn's disease treated with infliximab. Pharm. J. 2002, 2, 127-136. [CrossRef]

58. Gole, B.; Mian, E.; Rall, M.; Wiesmüller, L. Base excision repair proteins couple activation-induced cytidine deaminase and endonuclease G during replication stress-induced MLL destabilization. Leukemia 2018, 32, 159-167. [CrossRef]

59. Konikoff, M.R.; Denson, L.A. Role of fecal calprotectin as a biomarker of intestinal inflammation in inflammatory bowel disease. Inflamm. Bowel Dis. 2006, 6, 524-534. [CrossRef]

60. Luther, J.; Gala, M.; Patel, S.J.; Dave, M.; Borren, N.; Xavier, R.J.; Ananthakrishnan, A.N. Loss of Response to Anti-Tumor Necrosis Factor Alpha Therapy in Crohn's Disease Is Not Associated with Emergence of Novel Inflammatory Pathways. Dig. Dis. Sci. 2018, 63, 738-745. [CrossRef]

61. Yamamoto, K.; Chiba, T.; Matsumoto, T. Effect of tumor necrosis factor- $\alpha$ antagonists on oxidative stress in patients with Crohn's disease. World J. Gastroenterol. 2015, 21, 10208-10214. [CrossRef] [PubMed]

62. Andersen, V.; Holmskov, U.; Sørensen, S.B.; Jawhara, M.; Andersen, K.W.; Bygum, A.; Hvid, L.; Grauslund, J.; Wied, J.; Glerup, H.; et al. A Proposal for a Study on Treatment Selection and Lifestyle Recommendations in Chronic Inflammatory Diseases: A Danish Multidisciplinary Collaboration on Prognostic Factors and Personalised Medicine. Nutrients 2017, 9, 499. [CrossRef] [PubMed]

63. Vermeire, S.; Louis, E.; Rutgeerts, P.; De Vos, M.; Van Gossum, A.; Belaiche, J.; Pescatore, P.; Fiasse, R.; Pelckmans, P.; Vlietinck, R.; et al. NOD2/CARD15 does not influence response to infliximab in Crohn's disease. Gastroenterology 2002, 123, 106-111. [CrossRef] [PubMed]

64. Mascheretti, S.; Hampe, J.; Croucher, P.J.; Nikolaus, S.; Andus, T.; Schubert, S.; Olson, A.; Bao, W.; Fölsch, U.R.; Schreiber, S. Response to infliximab treatment in Crohn's disease is not associated with mutations in the CARD15 (NOD2) gene: An analysis in 534 patients from two multicenter, prospective GCP-level trials. Pharmacogenetics 2002, 12, 509-515. [CrossRef] [PubMed]

65. Pierik, M.; Vermeire, S.; Steen, K.V.; Joossens, S.; Claessens, G.; Vlietinck, R.; Rutgeerts, P. Tumour necrosis factor-alpha receptor 1 and 2 polymorphisms in inflammatory bowel disease and their association with response to infliximab. Aliment. Pharmacol. Ther. 2004, 20, 303-310. [CrossRef]

66. Palmieri, O.; Latiano, A.; Valvano, R.; D’Incà, R.; Vecchi, M.; Sturniolo, G.C.; Saibeni, S.; Bossa, F.; Latiano, T.; Devoto, M.; et al. Multidrug resistance 1 gene polymorphisms are not associated with inflammatory bowel disease and response to therapy in Italian patients. Aliment. Pharmacol. Ther. 2005, 22, 1129-1138. [CrossRef] [PubMed] 
67. Willot, S.; Vermeire, S.; Ohresser, M.; Rutgeerts, P.; Paintaud, G.; Belaiche, J.; De Vos, M.; Van Gossum, A.; Franchimont, D.; Colombel, J.F.; et al. No association between C-reactive protein gene polymorphisms and decrease of C-reactive protein serum concentration after infliximab treatment in Crohn's disease. Pharm. Genom. 2006, 16, 37-42. [CrossRef]

68. Dideberg, V.; Théâtre, E.; Farnir, F.; Vermeire, S.; Rutgeerts, P.; De Vos, M.; Belaiche, J.; Franchimont, D.; Van Gossum, A.; Louis, E.; et al. The TNF/ADAM 17 system: Implication of an ADAM 17 haplotype in the clinical response to infliximab in Crohn's disease. Pharm. Genom. 2006, 16, 727-734. [CrossRef] [PubMed]

69. Louis, E.J.; Watier, H.E.; Schreiber, S.; Hampe, J.; Taillard, F.; Olson, A.; Thorne, N.; Zhang, H.; Colombel, J.F. Polymorphism in IgG Fc receptor gene FCGR3A and response to infliximab in Crohn's disease: A subanalysis of the ACCENT I study. Pharm. Genom. 2006, 16, 911-914. [CrossRef]

70. Fischer, S.; Lakatos, P.L.; The Hungarian IBD Study Group; Lakatos, L.; Kovacs, A.; Molnár, T.; Altorjay, I.; Papp, M.; Szilvasi, A.; Tulassay, Z.; et al. ATP-binding cassette transporter ABCG2 (BCRP) and ABCB1 (MDR1) variants are not associated with disease susceptibility, disease phenotype response to medical therapy or need for surgeryin Hungarian patients with inflammatory bowel diseases. Scand. J. Gastroenterol. 2007, 42, 726-733. [CrossRef]

71. Matsukura, H.; Ikeda, S.; Yoshimura, N.; Takazoe, M.; Muramatsu, M. Genetic polymorphisms of tumour necrosis factor receptor superfamily $1 \mathrm{~A}$ and $1 \mathrm{~B}$ affect responses to infliximab in Japanese patients with Crohn's disease. Aliment. Pharmacol. Ther. 2008, 27, 765-770. [CrossRef] [PubMed]

72. Meuwis, M.A.; Fillet, M.; Lutteri, L.; Marée, R.; Geurts, P.; de Seny, D.; Malaise, M.; Chapelle, J.P.; Wehenkel, L.; Belaiche, J.; et al. Proteomics for prediction and characterization of response to infliximab in Crohn's disease: A pilot study. Clin. Biochem. 2008, 41, 960-967. [CrossRef] [PubMed]

73. Weiss, B.; Lebowitz, O.; Fidder, H.H.; Maza, I.; Levine, A.; Shaoul, R.; Reif, S.; Bujanover, Y.; Karban, A. Response to medical treatment in patients with Crohn's disease: The role of NOD2/CRAD15, disease phenotype, and age of diagnosis. Dig. Dis. Sci. 2010, 55, 1674-1680. [CrossRef] [PubMed]

74. Jürgens, M.; Mahachie John, J.M.; Cleynen, I.; Schnitzler, F.; Fidder, H.; van Moerkercke, W.; Ballet, V.; Noman, M.; Hoffman, I.; van Assche, G.; et al. Levels of C-reactive protein are associated with response to infliximab therapy in patients with Crohn's disease. Clin. Gastroenterol. Hepatol. 2011, 9, 421-427. [CrossRef] [PubMed]

75. Niess, J.H.; Klaus, J.; Stephani, J.; Pflüger, C.; Degenkolb, N.; Spaniol, U.; Mayer, B.; Lahr, G.; von Boyen, G.B. NOD2 polymorphism predicts response to treatment in Crohn's disease-first steps to a personalized therapy. Dig. Dis. Sci. 2012, 57, 879-886. [CrossRef] [PubMed]

76. Dige, A.; Støy, S.; Rasmussen, T.K.; Kelsen, J.; Hvas, C.L.; Sandahl, T.D.; Dahlerup, J.F.; Deleuran, B.; Agnholt, J. Increased levels of circulating Th17 cells in quiescent versus active Crohn's disease. J. Crohn's Colitis 2013, 7, 248-255. [CrossRef] [PubMed]

77. Perrier, C.; Arijs, I.; Staelens, D.; Breynaert, C.; Cleynen, I.; Covens, K.; Ferrante, M.; Van Assche, G.; Vermeire, S.; de Hertogh, G.; et al. Interleukin-15 receptor $\alpha$ expression in inflammatory bowel disease patients before and after normalization of inflammation with infliximab. Immunology 2013, 138, 47-56. [CrossRef]

78. Lu, C.; Waugh, A.; Bailey, R.J.; Cherry, R.; A Dieleman, L.; Gramlich, L.; Matic, K.; Millan, M.; I Kroeker, K.; Sadowski, D.; et al. Crohn's disease genotypes of patients in remission vs relapses after infliximab discontinuation. World J. Gastroenterol. 2012, 18, 5058-5064. [CrossRef]

79. Moroi, R.; Endo, K.; Kinouchi, Y.; Shiga, H.; Kakuta, Y.; Kuroha, M.; Kanazawa, Y.; Shimodaira, Y.; Horiuchi, T.; Takahashi, S.; et al. FCGR3A-158 polymorphism influences the biological response to infliximab in Crohn's disease through affecting the ADCC activity. Immunogenetics 2013, 65, 265-271. [CrossRef]

80. Gutiérrez, A.; Scharl, M.; Sempere, L.; Holler, E.; Zapater, P.; Almenta, I.; González-Navajas, J.M.; Such, J.; Wiest, R.; Rogler, G.; et al. Genetic susceptibility to increased bacterial translocation influences the response to biological therapy in patients with Crohn's disease. Gut 2014, 63, 272-280. [CrossRef]

81. Boschetti, G.; Garnero, P.; Moussata, D.; Cuerq, C.; Préaudat, C.; Duclaux-Loras, R.; Mialon, A.; Drai, J.; Flourié, B.; Nancey, S. Accuracies of serum and fecal S100 proteins (calprotectin and calgranulin C) to predict the response to TNF antagonists in patients with Crohn's disease. Inflamm. Bowel Dis. 2015, 21, 331-336. [CrossRef] [PubMed] 
82. Váradi, C.; Holló, Z.; Poliska, S.; Nagy, L.; Szekanecz, Z.; Váncsa, A.; Palatka, K. Combination of IgG $\mathrm{N}$-glycomics and corresponding transcriptomics data to identify anti-TNF- $\alpha$ treatment responders in inflammatory diseases. Electrophoresis 2015, 36, 1330-1335. [CrossRef] [PubMed]

83. Vatansever, A.; Çekiç, C.; Ekinci, N.; Yüksel, E.S.; Avcı, A.; Aslan, F.; Arabul, M.; Ünsal, B.; Çakalağaoğlu, F. Effects of mucosal TNF-alpha levels on treatment response in Crohn's disease patients receiving anti-TNF treatment. Hepatogastroenterology 2014, 61, 2277-2282. [PubMed]

84. Rapti, E.; Gazouli, M.; Legaki, E.; Karamanolis, G.; Thomas, D.; Marinos, E.; Papaconstantinou, I. Association of survivin promoter polymorphisms with inflammatory bowel disease and response to antitumor necrosis factor therapy. Genet. Test. Mol. Biomark. 2015, 19, 339-343. [CrossRef] [PubMed]

85. Medrano, L.M.; Taxonera, C.; González-Artacho, C.; Pascual, V.; Gómez-García, M.; Acosta, M.B.-D.; Perez-Calle, J.L.; Bermejo, F.; López-Sanromán, A.; Arranz, D.M.; et al. Response to Infliximab in Crohn's Disease: Genetic Analysis Supporting Expression Profile. Mediat. Inflamm. 2015, 2015, 1-8. [CrossRef] [PubMed]

86. Urabe, S.; Isomoto, H.; Ishida, T.; Maeda, K.; Inamine, T.; Kondo, S.; Higuchi, N.; Sato, K.; Uehara, R.; Yajima, H.; et al. Genetic Polymorphisms of IL-17F and TRAF3IP2 Could Be Predictive Factors of the Long-Term Effect of Infliximab against Crohn's Disease. BioMed Int. 2015, 2015, 1-12. [CrossRef] [PubMed]

87. Bank, S.; Andersen, P.S.; Burisch, J.; Pedersen, N.; Roug, S.; Galsgaard, J.; Turino, S.Y.; Brodersen, J.B.; Rashid, S.; Rasmussen, B.K.; et al. Genetically determined high activity of IL-12 and IL-18 in ulcerative colitis and TLR5 in Crohns disease were associated with non-response to anti-TNF therapy. Pharm. J. 2018, 18, 87-97. [CrossRef]

88. Papaconstantinou, I.; Kapizioni, C.; Legaki, E.; Xourgia, E.; Karamanolis, G.; Gklavas, A.; Gazouli, M. Association of miR-146 rs2910164, miR-196a rs11614913, miR-221 rs113054794 and miR-224 rs188519172 polymorphisms with anti-TNF treatment response in a Greek population with Crohn's disease. World J. Gastrointest. Pharmacol. Ther. 2017, 8, 193-200. [CrossRef] [PubMed] 